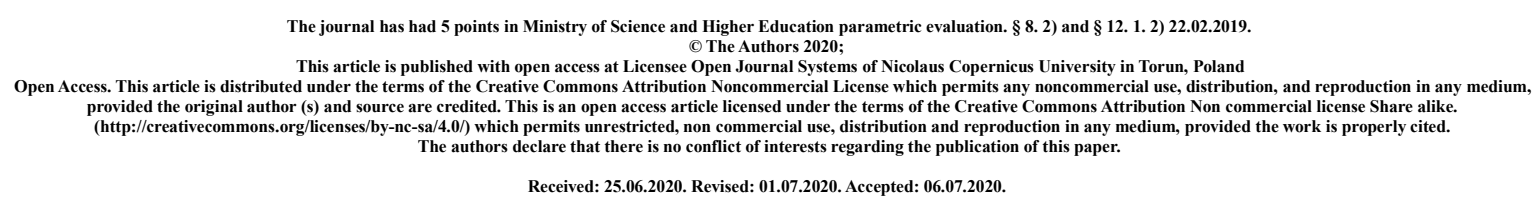

\title{
Accounting Firm Customer Satisfaction Survey
}

\section{Mgr Izabela Bagińska}

\section{Częstochowa University of Technology}

\section{Management Department}

\begin{abstract}
Competition on the market means that the accounting firms that wish to maintain their position on the market, must seek ways to convince their customers that the services they offer are competitive to those offered by their competitors. An accounting firm must convince the company that it will meet all its needs and that it will guarantee proper quality. This article aims to identify the factors determining the quality of services provided by accounting firms. The first part of the study contains a review of the literature on service quality and satisfaction as an important factor in its development. The second part contains the results of an anonymous survey conducted among the companies that benefit from accounting outsourcing. The five-level Likert scale was used in the questionnaire. The survey indicated that the respective factors affect the quality and satisfaction of accounting services provided by accounting firms to a different extent.
\end{abstract}

Key words: accounting outsourcing; service quality

\section{Introduction}

In an extremely turbulent environment, companies wishing to maintain their market position must adapt their services to the changing and growing requirements of their customers. A company using outsourcing must be certain that the quality of services provided by an external entity is at the highest level. There is a lot of competition among service firms, with which businesses try to fight using various tools. 
The service sector has become more and more important in recent years. It accounts for $60 \%$ of the value-added in the European Economic Community (EEC) ${ }^{1}$. Quality improvement is a key issue in many service companies. Despite the importance of the service sector, the condition of research and publications on service quality is insufficient.

Initially, the quality was characterized by a certain degree of excellence. Over the years, the concept of development evolved, which was associated with social change and technological progress. In the 1950s, quality meant the usefulness of the product. Over time, the quality of service has become a major area of interest for researchers, due to its impact on economic activity ${ }^{2}$.

As regards quality, companies mainly demonstrate an approach typical for quality management systems, where quality is assessed as the degree to which pre-established standards and procedures are met and followed ${ }^{3}$. For an accounting firm to gain a high position among its competitors, the quality of its services must be recognized primarily by the customers. The customer determines the strategy of activity and the manners of its implementation.

One of the ways for an accounting firm to gain a permanent position on the market is to achieve an appropriate level of quality of the services offered which meet the growing requirements of companies. Contemporary studies mainly distinguish between quality in technical (quality as the property determining the degree of suitability for use), economic (degree of compliance), and marketing (customer satisfaction) terms ${ }^{4}$.

The issue of service quality has been extensively examined in the field of economic sciences. There are articles on quality management, where you can find general works on marketing, management and quality, and studies on the concepts, methods, and techniques of quality management.

An important foreign publication is P. Kotler's Principles of marketing, in which the author explains in detail the essence of management and stresses the importance of satisfaction in building relationships with customers ${ }^{5}$. Also noteworthy is the work by W. E. Deming, who described the successive stages of rational thinking and acting towards quality,

\footnotetext{
${ }^{1}$ Ghobadian, Abby, Simon Speller, and Matthew Jones. "Service quality." International journal of quality \& reliability management (1994).

${ }^{2}$ Seth, Nitin, S.G. Deshmukh, and Prem Vrat. "Service quality models: a review." International journal of quality \& reliability management (2005).

3J.M. Yuran: Juran on Quality by Design, FREE PRESS, New Zork 1992, p. 10.

4 Jain P. Aggarval V., ."Service quality models: a review" BVIMSR's Journal of Management Research, vol. 7, no 2, pp. 125-136, Oct. 2015

${ }^{5}$ P. Kotler, G. Armstrong, Principles of marketing. New Jersey 2010; confer: P. Kotler [et al.], Marketing. Podręcznik europejski. (European handbook.) Warsaw 2002.
} 
called the Deming Cycle. His reflections are still valid today and form the basis of many modern methods of quality management ${ }^{6}$.

An important place in Polish studies is occupied by a collective publication edited by Janusz Toruński, in which the authors presented the most important issues related to quality management in a systematic manner ${ }^{7}$. The issues related to quality management are also of interest to economic universities.

\section{Quality management and customer satisfaction}

There is no single definition of quality. This concept has a broad meaning and often depends on the context in which it is used. This article presents different approaches to defining quality because they form a coherent whole.

Already in antiquity, the understanding of quality took different forms. Plato identified quality with the degree of excellence achieved, which is assessed from the experience. Aristotle, on the other hand, saw it as one of ten categories that make it possible to divide all concepts into logical groups ${ }^{8}$.

Different approaches by philosophers to quality have had an impact on the specification of different types of quality in terms of specific criteria. Modern studies distinguish quality mainly9:

- $\quad$ in technical terms, as:

a) conformity of a choice with a standard,

b) a set of physical, chemical and biological characteristics of a good or service,

c) characteristics determining the degree of usefulness,

- $\quad$ in economic terms, as a certain level of compliance to requirements,

- $\quad$ in marketing terms, like customer satisfaction.

The various definitions of the concept of quality have led to several quality management concepts in the literature, which often have different objectives and relate to quality assurance in different ways. The following concepts are worth mentioning:

- the concept by William Edwards Deming, who presented 14 points $^{10}$ :

a) responsibility of the company's management,

\footnotetext{
${ }^{6}$ W. E. Deming, Out of the Crisis. Cambridge 2000.

7Zarządzanie jakością w przedsiębiorstwie: wybrane problemy (Quality management in the company: selected problems), ed. J. Toruński. Siedlce 2012

${ }^{8}$ Horbaczewski D., "Philosophical Sources of the Modern Understanding of Quality" ("Filozoficzne źródła współczesnego pojmowania jakości”) Quality Problems, vol. 10, pp. 9-12 ,Oct 2006.

9 Jain P. Aggarval V., op. cit., p. 131.

${ }^{10} \mathrm{~A}$. Mazur, H. Gołaś, Zasady, metody i techniki wykorzystywane w zarządzaniu jakością. (Principles, methods and techniques used in quality management.) Poznań 2010, pp. 57-58.
} 
b) rejection of bad habits and learning of the new philosophy,

c) getting rid of mass control,

d) decisions based on quality, not on price,

e) continuous improvement of processes,

f) training and coaching,

g) appropriate supervision methods,

h) elimination of fear,

i) removal of communications barriers,

j) getting rid of slogans and admonitions,

k) elimination of numerical targets,

1) pride of work,

$\mathrm{m})$ education and training,

n) universal commitment.

- the concept by Joseph Juran - the author perceived quality as usefulness beyond the statistical dimension of quality management or compliance with specifications. He believed that quality is determined by the user, and not by the producer ${ }^{11}$,

- the concept by Armand Feigenbaum - he emphasized activating activities at the horizontal level. According to that author, quality management requires ${ }^{12}$ :

a) separating the activities of quality planning and programming from operational activities of quality control and regulation within the current production processes;

b) creating organizational mechanisms to efficiently coordinate quality activities;

c) concentrating specialists on developing control methods and means of operation.

- the concept by Philip Crosby's, which is based on four premises ${ }^{13}$ :

a) quality is about meeting customer expectations, not the perfection of performance;

b) it is more important to avoid quality errors than to correct them;

c) the quality standard means absolute absence of errors and not an acceptable level of errors;

d) the measure of quality is the price of compliance with the specification, not the value of indicators.

\footnotetext{
11J. Łańcucki, Jakość usług (Quality of services), Problemy Jakości No. 8/1997, p. 40.

${ }^{12}$ Ibidem, p. 36.

${ }^{13}$ Mazur A., Gołaś H., Zasady, metody i techniki wykorzystywane w zarządzaniu jakością. (Principles, methods and techniques used in quality management.) Wydawnictwo Politechniki Poznańskiej, Poznań 2010., pp. 5556.
} 
- the concept by Kaoru Ishikawa - the author emphasized the value of customer satisfaction. He believed that quality should be defined from a product that satisfies the customer to the highest degree ${ }^{14}$,

- the Total Quality Management concept, which focuses on quality and emphasises the participation of all company employees in quality development. It is aimed at achieving long-term success by satisfying the customer and all members of the organization. The most important principles of TQM are ${ }^{15}$ :

a) orientation towards the good quality of products and services,

b) establishment of the main purpose of the organization per pro-quality policy,

c) participation of employees in the management process,

d) employee training,

e) creation of problem-solving teams,

f) conduct of surveys using statistical methods,

g) long-term planning,

h) convincing employees that effectiveness depends on the organization as a whole and not just on the respective employees.

In common sense, satisfaction means satisfaction with the consumption of products or services. Although many authors associated satisfaction with the quality of services provided, these are not the same concepts. The term satisfaction derives from the Latin words: satis enough and facere - to do, so according to the source, it is the term for a correctly performed activity. Different understandings of the term "satisfaction" have given rise to several models of customer satisfaction ${ }^{16}$.

1. The emotional model is an emotional evaluation of the results of the service provided. The customer assesses the result on the following level: success - failure or satisfaction - lack of satisfaction.

2. A model based on the theory of fairness of exchange - customer satisfaction occurs when the ratio of their benefits from owning a product or service to outlays is fair. This

an assessment of the profits and costs of both parties to the transaction.

\footnotetext{
${ }^{14}$ Stoma M., Modele i metody pomiaru jakości usług. (Models and methods for measuring service quality.) Q\&R Polska, Lublin 2012.

${ }^{15}$ Zarządzanie jakością usług w instytucjach publicznych (Service quality management in public institutions), ed. J. Frąś. Szczecin 2008, pp. 34-35.

${ }^{16}$ M. Hałat-Łaś, M. Łaś, M. Gaweł, Ł. Makowski, Modele i metody badania satysfakcji klienta (Models and methods of customer satisfaction surveys), Zeszyty Naukowe Wyższej Szkoły Bankowej w Wrocławiu, No. 6/2014, Wrocław 2014, p. 32.
} 
3. Anticipated Non-Conformity Model - satisfaction is achieved based on experience with the product or service.

4. The Kano model - it distinguishes between three types of satisfaction:

- necessary satisfaction

- one-dimensional satisfaction

- overachievement

5. The PROSAT model - Satisfaction is understood as a feeling perceived by the consumer and not the objective quality of a product or service.

The activities of accounting firms are regulated by the Accounting Act. That document defines the accounting firms as the entities that provide the services of keeping the accounting books. Following chapter $8 \mathrm{a}$, bookkeeping services may be performed by the entrepreneurs that ${ }^{17}$ :

- have full legal capacity;

- have not been convicted of an offence against the validity of documents, property, business, money or securities trading, a fiscal offence or for the offences specified in chapter 9.

\section{Checking the quality of accounting services}

A survey was conducted among the customers of accounting firms, using survey questionnaires. The survey was anonymous. The study used the five-level Likert scale, where 1 means "strongly agree" and 5 means "strongly disagree". The survey was conducted among the entrepreneurs who conduct business activity in the Częstochowa region and outsource tax consulting services. The structure of the survey respondents is presented in Figure 1.

Figure 1. Structure of respondents

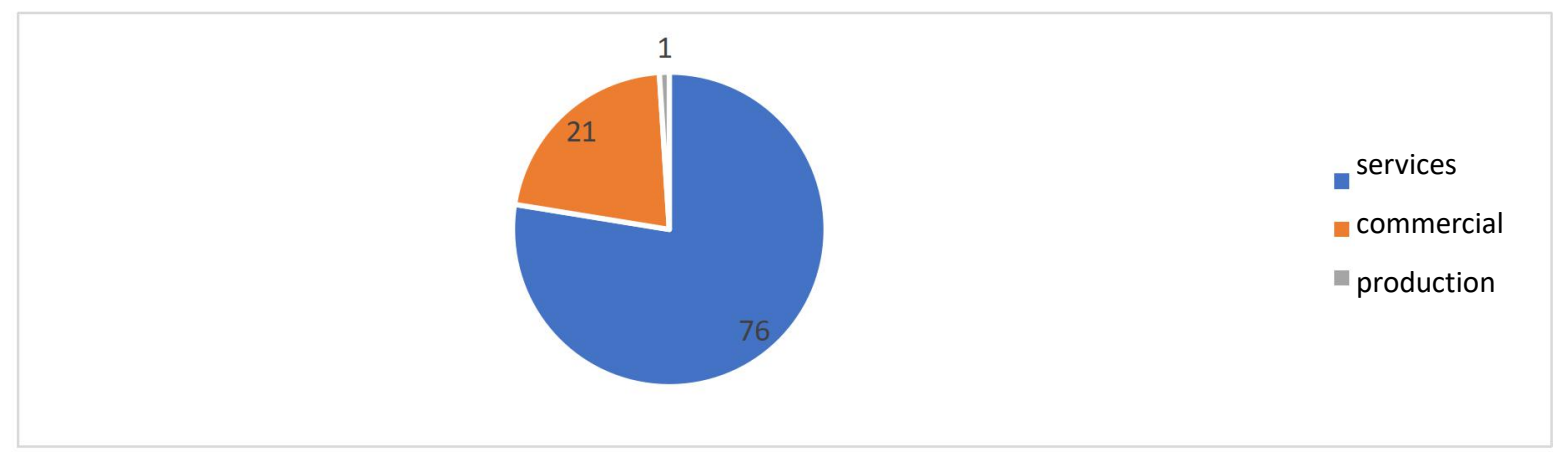

The first statement in the questionnaire was: Price is the most important determinant of the quality of accounting service. It turns out that most of the respondents do not agree or

17 Accounting Act of 29 September 1994 (Journal of Laws 2019.351 of 22 February 2019), art. 76a, section 3. 
strongly disagree with this statement (34\% strongly disagree and 21\% do not agree), $28 \%$ do not have an opinion, while negative answers were given by $17 \%$.

Figure 2 Price as the main determinant of the quality of accounting service

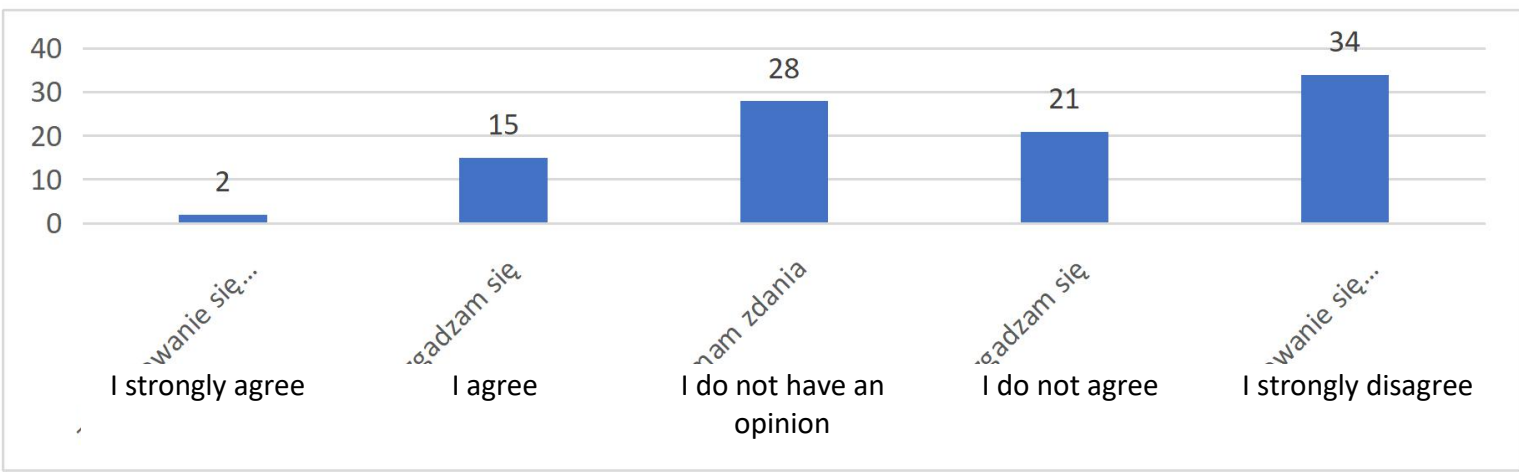

The next statement in the study was: The choice of an accounting firm is crucial for the quality of service and customer satisfaction. Contrary to the previous statement, the highest percentage of respondents answered in the affirmative (57\%), 22\% have no opinion on

the subject and $21 \%$ do not agree with this statement.

Figure 3. Selection of an accounting firm as the main determinant of the quality of accounting services and customer satisfaction

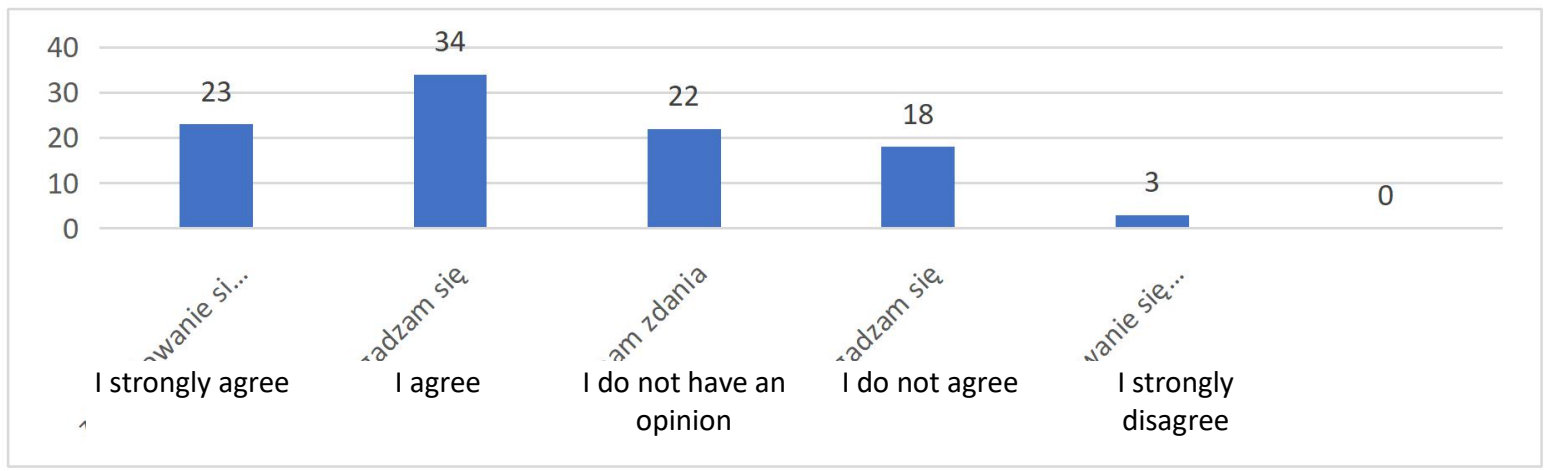

The next statement in the questionnaire was: The inspection of cooperation with an accounting firm is a determinant of the quality of accounting services and satisfaction of accounting firms' customers. It turns out that in the opinion of the respondents, the inspection of outsourcing cooperation does not translate into a better quality of accounting service. $15 \%$ of them strongly disagree with this statement, $36 \%$ do not agree with it and $18 \%$ have no opinion. Positive responses represent a small percentage (18\%). The results should be summed up with the conclusion that the inspection of an accounting firm's activities provides a level of quality and satisfaction with accounting services, but it is not the most important 
aspect.

Figure 4. Inspection of cooperation with an accounting service provider as the main determinant of the quality of accounting services and customer satisfaction

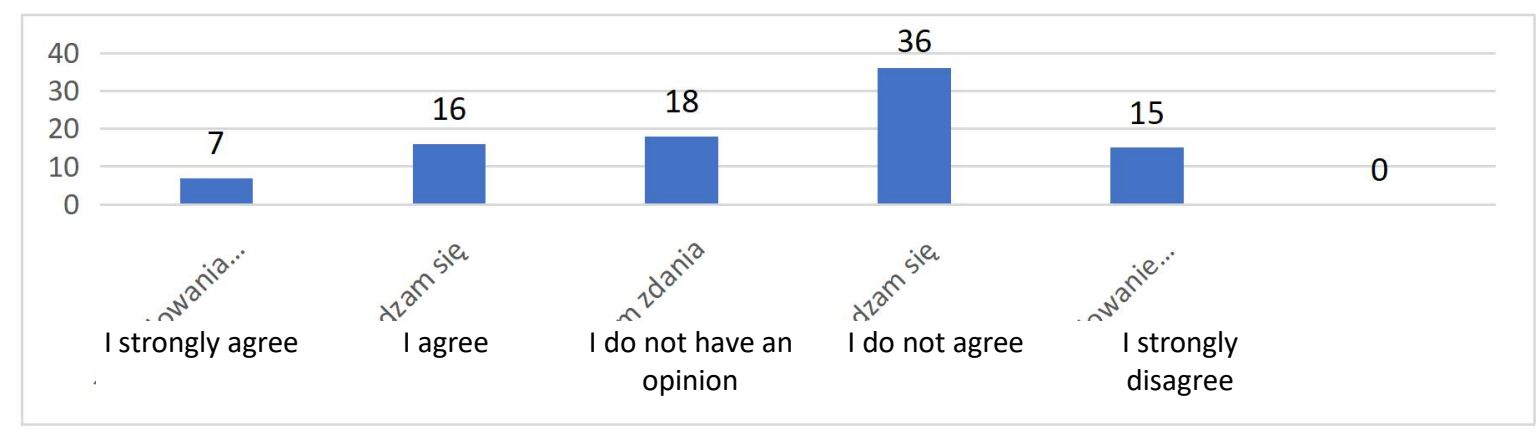

The next statement in the questionnaire was: The possibility to concentrate on the core business is a major determinant of the quality of accounting services and customer satisfaction. The results leave no doubt - the possibility to focus on core business is seen as one of the main determinants by almost all the respondents. 53\% strongly agree, $42 \%$ agree, while $5 \%$ have no opinion.

Figure 5. The possibility to focus on core business as a key determinant of the quality of accounting services and customer satisfaction

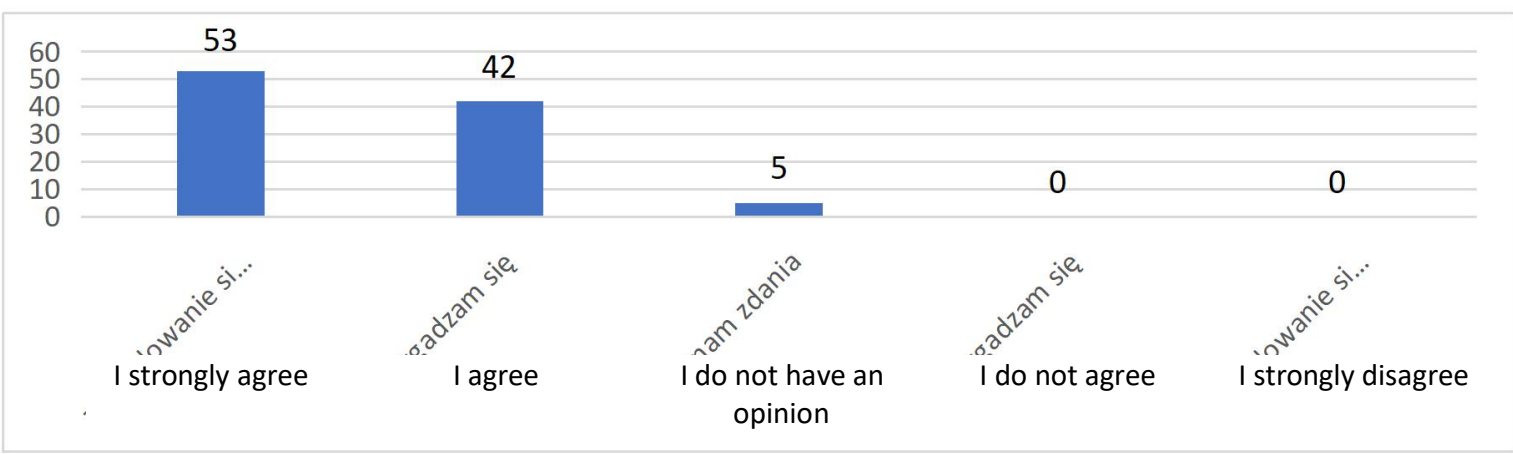

The next statement in the questionnaire was: Proper qualifications are the main determinants of the quality of accounting services and customer satisfaction. The results were clear. All respondents answered in the affirmative (67\% strongly agree and 33\% agree). Therefore, it is appropriate to agree with the statement that appropriate qualifications guarantee the quality of accounting services. This should therefore be one of the main criteria for selecting an accounting firm as the accounting service provider. 
Figure 6. Appropriate qualifications as the main determinant of the quality of accounting services and customer satisfaction

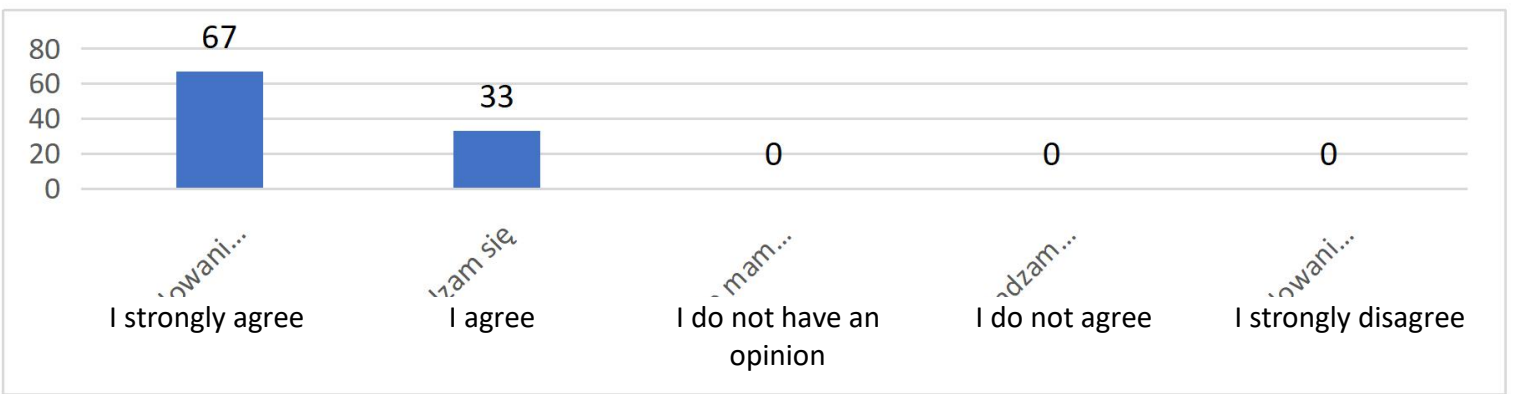

The last statement of the survey questionnaire was: The development of new technologies has a significant impact on the quality of accounting services and customer satisfaction. Here too, the majority of entrepreneurs agreed with this statement ( $41 \%$ strongly agree and $24 \%$ agree). $18 \%$ of respondents gave negative answers and $17 \%$ have no opinion on the matter. It should be concluded that the companies surveyed consider that the development of new technologies translates into a better quality of services provided by accounting firms.

Figure 7. Development of new technologies as the main determinant of quality of accounting services and customer satisfaction

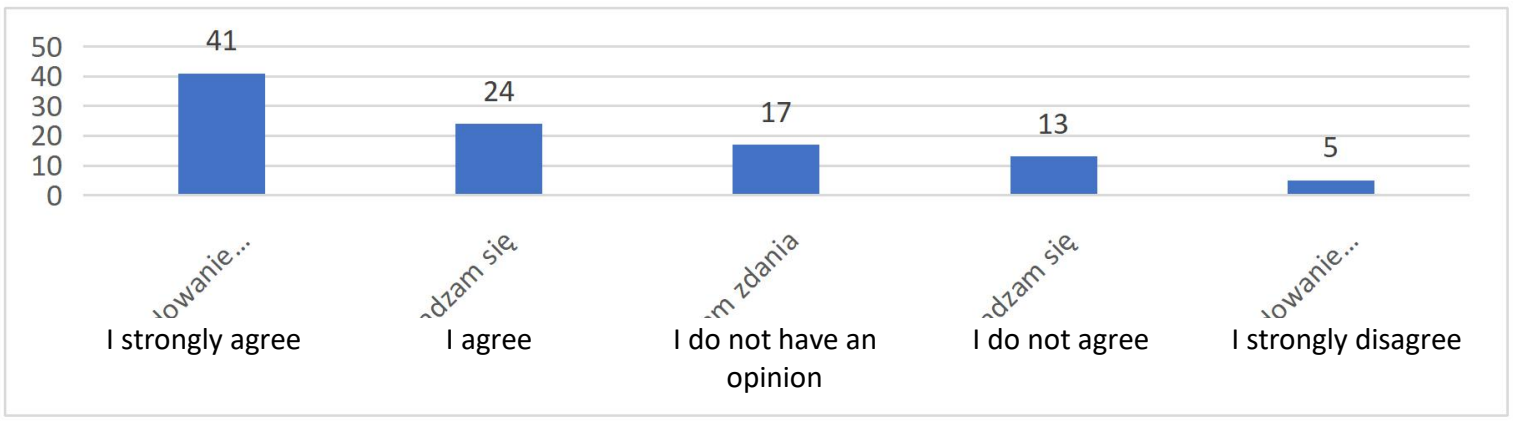

\section{Conclusions}

Today's market for goods and services is characterized by steadily increasing competition. It is also subject to constant technological changes. No wonder that in these conditions, quality is becoming an important factor in the struggle for customers. Companies seeking to gain a market advantage must convince customers that their services are competitive and of high quality. A satisfied customer is a loyal customer, which guarantees long-term cooperation.

Companies that are oriented towards gaining a market advantage should pay great attention to the quality of services offered. The measure of quality should be customer 
satisfaction, which can be achieved by offering a service in line with customers' needs and expectations. To continuously improve the quality of the accounting services offered, it is also necessary to verify the level of customer satisfaction with the quality of services provided.

When choosing an accounting firm, entrepreneurs think about the quality of accounting services offered by the firms. Until 2014, i.e. until the entry into effect of the deregulation,

the quality of accounting services had been determined by holding an accounting certificate. Until then, each accountant running an accounting firm had been required to have an accounting certificate. As of 10 August 2014, this obligation was abolished, so it is important to

choose

the right accounting firm as an outsourcing partner ${ }^{18}$.

Growing competition on the market of accounting services has caused accounting firms to adapt their offer to the customer, thus offering him a service tailored individually to the specifics of the given business as well as the requirements of the customer. Additionally, by responding to the customer's expectations, they offer a comprehensive service, often combining tax, legal, and financial advice.

The quality of services offered by accounting firms is undoubtedly influenced by the development of technology. The rapid development of IT systems has translated into a reduction in the time needed to perform certain activities and procedures. Through the use of the latest technological solutions, accounting firms guarantee high quality of services to their customers.

It turns out that the price, although still important, is not the main determinant of the quality of accounting services. Also, an inspection of outsourcing cooperation does not guarantee a better quality of services and does not translate into customer satisfaction.

The study also shows that the quality of the services offered by the accounting firm is significantly influenced by the possibility to concentrate on the core business. An entrepreneur who, thanks to the high quality of accounting services, can focus on activities that bring generate tangible benefits, is satisfied with the outsourcing cooperation.

\section{Bibliography}

1. Deming W. E., Out of the Crisis. Cambridge 2000.

2. Ghobadian, Abby, Simon Speller, and Matthew Jones. "Service quality." International

\footnotetext{
${ }^{18}$ Act on facilitating access to certain regulated professions of 9 May 2014. Journal of Laws of 2014, item 768.
} 
journal of quality \& reliability management (1994).

3. Hałat-Łaś M., Łaś M. Gaweł M., Makowski Ł., Modele i metody badania satysfakcji klienta (Models and methods of customer satisfaction surveys), Zeszyty Naukowe Wyższej Szkoły Bankowej w Wrocławiu, No. 6/2014, Wrocław 2014, p. 32.

4. Horbaczewski D., "Philosophical Sources of the Modern Understanding of Quality" (“Filozoficzne źródła współczesnego pojmowania jakości”) Quality Problems, vol. 10, pp. 9-12, Oct 2006.

5. Juran J. M., Juran on Quality by Design, FREE PRESS, New York 1992, p. 10.

6. Kotler P., Armstrong G., Principles of marketing. New Jersey 2010; confer: P. Kotler [et al.], Marketing. Podręcznik europejski. (European handbook.) Warsaw 2002.

7. Łańcucki J., Jakość usług (Quality of services), Problemy Jakości Nr 8/1997, p. 40.

8. Mazur A., Gołaś H., Zasady, metody i techniki wykorzystywane w zarządzaniu jakością. (Principles, methods and techniques used in quality management.) Poznań 2010, pp. 57-58.

9. Seth, Nitin, S. G. Deshmukh, and Prem Vrat. "Service quality models: a review." International journal of quality \& reliability management (2005).

10. Stoma M., Modele i metody pomiaru jakości usług. (Models and methods for measuring service quality.) Q\&R Polska, Lublin 2012.

11. Zarządzanie jakością w przedsiębiorstwie: wybrane problemy (Quality management in the company: selected problems), ed. J. Toruński. Siedlce 2012.

12. Zarządzanie jakością usług $\mathrm{w}$ instytucjach publicznych (Service quality management in public institutions), ed. J. Frąś. Szczecin 2008, pp. 34-35.

Legislation:

1. Accounting Act of 29 September 1994 (Journal of Laws 2019.351 of 22 February 2019).

2. Act on facilitating access to certain regulated professions of 9 May 2014. Journal of Laws of 2014 , item 768 . 